\title{
Analisis Status Kelangsungan Hidup Penderita Penyakit Diabetes Mellitus (DM) RS.Wahidin Sudirohusodo Makassar Dengan Model Regresi Logistik Nominal
}

\begin{abstract}
Anisa* $^{*}$
Abstrak

Status kelangsungan hidup pasien penderita penyakit tertentu merupakan hal yang penting untuk dikaji. Dalam penelitian ini dilakukan analisis terhadap status kelangsungan hidup pasien penderita penyakit Diabetes Mellitus (DM) di RS. Wahidin Sudirohusodo Makassar periode Januari 2005 sampai dengan Mei 2006. Model regresi Logistik Nominal digunakan dalam analisis ini, karena terdapat 4 kategori status kelangsungan hidup pasien, yaitu sembuh, belum sembuh atau pulang paksa, membaik atau berobat jalan dan meninggal. Hasil penelitian menunjukkan bahwa peluang untuk membaik atau berobat jalan pasien penderita penyakit ini adalah 0.99. Peluang belum sembuh atau pulang paksa adalah 0.32 , sedangkan peluang sembuh adalah 0, jika status meninggal dijadikan sebagai kategori acuan. Hasil pengujian secara keseluruhan menunjukkan bahwa model yang dihasilkan cukup layak relatif terhadap data yang digunakan (nilai $p$-value $<\alpha=0.05$ ).
\end{abstract}

Kata Kunci : algoritma status kelangsungan hidup, model regresi Logistik Nominal.

\section{Pendahuluan}

Pada 10 tahun terakhir ini, aplikasi dari metode statistika dibidang kesehatan dikembangkan secara luas melebihi ilmu yang menyangkut tentang kesehatan dan penelitian pada bidang lain, seperti kriminologi, sosiologi, pemasaran, dan asuransi kesehatan. Analisis status kelangsungan hidup merupakan suatu analisis yang digunakan untuk mengetahui peluang ratarata kelangsungan hidup penderita penyakit selama jangka waktu tertentu (Lee, 1992). Pada umumnya, tujuan dilakukannya analisis status kelangsungan hidup adalah untuk mengidentifikasi variabel ramalan yang penting untuk waktu kelangsungan hidup atau untuk membandingkan waktu kelangsungan hidup dari beberapa kelompok yang berbeda.

Menentukan berapa peluang dapat bertahan hidupnya suatu individu merupakan hal penting dalam analisis status kelangsungan hidup. Untuk itu ada beberapa metode pendugaan yang dapat dilakukan, baik secara parametrik, misalnya dengan regresi Cox dan regresi Logistik, maupun non-parametrik dengan metode Aktuaria dan Kaplan-Meier. Pendugaan secara parametrik dilakukan apabila objek atau individu diamati dan diukur pada interval waktu yang sama, sedangkan pendugaan secara non-parametrik dilakukan apabila objek atau individu diamati dan diukur dalam interval waktu yang tidak sama. Penelitian ini akan difokuskan pada penggunaan metode parametrik dengan menggunakan regresi Logistik, dimana pada kasus ini peubah respon kategorik bersifat politomus atau terdapat beberapa kategori (Hosmer \&

* Staf pengajar pada Jurusan Matematika FMIPA Universitas Hasanuddin Makassar

(Email : nkalondeng@yahoo.com) 


\section{Anisa}

Lemeshow, 1989). Model-model respon politomus disebut dengan model logit Multinomial, karena fungsi penghubung (link function) yang digunakan adalah multinomial (Hosmer \& Lemeshow, 1989). Model ini dapat dikelompokkan ke dalam dua kelas model yang berbeda tergantung pada apakah peubah respon mempunyai struktur kategori yang terurut (ordered) atau tidak (unordered). Jika mempunyai struktur yang terurut, maka model regresi Logistik yang digunakan adalah regresi Logistik Ordinal atau dikenal regresi Ordinal, sedangkan jika tidak digunakan model regresi Logistik Nominal. Hal utama yang menjadi alasan penggunaan regresi Logistik adalah fungsinya mudah dan fleksibel. Selain itu, fungsi ini dapat diinterpretasikan menjadi bentuk yang nyata (Tiro, 2004).

Pada penelitian ini, analisis status kelangsungan hidup pasien yang dikelompokkan dalam beberapa kategori, dilakukan dengan menggunakan model regresi Logistik Nominal pada pasien yang mengidap penyakit Diabetes Mellitus (DM) untuk mengetahui profil tingkat penyakit Diabetes Mellitus (DM) pasien dan faktor/variabel yang mempengaruhi tingkat penyakit tersebut. Juga akan diketahui profil pasien yang mengalami perbaikan atau sembuh selama dalam proses perawatan.

DM adalah suatu keadaan dimana terjadi peningkatan kadar gula (glukosa) dalam darah yang berlebihan dan terjadi secara menahun, hal ini terjadi karena tubuh tidak bisa memproduksi insulin dalam jumlah yang cukup atau tubuh tidak mampu menggunakan insulin secara efektif. Disebut penyakit Diabetes Mellitus, karena dalam urin penderita penyakit tersebut dapat ditemukan zat gula yang mana seharusnya tidak diketemukan (Tim Redaksi Vitahealth, 2004).

Terdapat dua jenis penyakit Diabetes Mellitus (DM) yaitu DM tipe I dan DM tipe II, dimana DM tipe I tergantung sepenuhnya pada insulin, pankreasnya secara terlahir tidak menghasilkan hormon insulin. Akibatnya dari kecil sampai tua, penderita ini sangat tergantung dengan hormon insulin buatan yang harus disuntikkan pada tiap saat tertentu. Umumnya DM tipe I ini diturunkan oleh orangtuanya. DM tipe II tidak tergantung pada insulin, tipe ini dimulai pada masa dewasa dikenal sebagai NIDDM (Non insulin dependen diabetes mellitus). Tipe ini seringkali tidak terdiagnosis pada awalnya dan terdeteksi setelah penyakit ini mulai menunjukkan komplikasi berupa kerusakan pada organ tubuh seperti mata, ginjal, saraf, gusi, gigi dan pembuluh darah. DM tipe II disebabkan oleh faktor obesitas (gemuk berlebihan), pola makan yang salah, proses penuaan, stress yang mengakibatkan terjadinya resistensi insulin, dan sebagainya. Jenis ini mewakili 90 persen dari seluruh kasus pada penderita penyakit ini, sehingga DM tipe II inilah yang akan menjadi fokus dalam penelitian ini.

\section{Model Regresi Logistik Nominal}

Model regresi Logistik Nominal digunakan jika kategori respon tidak terurut (unordered). Model ini merupakan pengembangan dari model regresi Logistik Biner yang menganalisis variabel respon yang hanya terdiri dari dua kategori saja, yaitu sukses atau gagal. Model ini sebagaimana model regresi Ordinal menggunakan fungsi penghubung (link function) logit multinomial.

Pada model regresi Logistik Nominal, salah satu kategori dapat dipilih sebagai kategori acuan (reference category), dimana pemilihan kategori ini tidak khas. Sembarang kategori $j(j=$ $1,2, \ldots, J)$ dapat dipilih sebagai kategori acuan.

Misalkan kategori acuan yang dipilih adalah kategori pertama. Maka logit untuk kategori lain didefinisikan sebagai

$$
\operatorname{logit}\left(\pi_{J}\right)=\log \left(\frac{\pi_{J}}{\pi_{1}}\right)=x_{J}{ }^{T} \beta_{j}, \text { untuk } j=2,3, \ldots, J
$$




\section{Anisa}

Keseluruhan $(J-1)$ logit digunakan untuk menduga parameter-parameter $\beta_{j}$. Jika penduga $b_{j}$ yang merupakan dugaan dari $\beta_{j}$ telah tersedia, maka penduga linear $x_{J}{ }^{T} \beta_{j}$ dapat dihitung. Dari persamaan (1) diperoleh

$$
\hat{\pi}_{J}=\hat{\pi}_{1} \exp \left(x_{J}{ }^{T} \beta_{j}\right) \text {, untuk } j=2,3, \ldots, J
$$

Karena $\hat{\pi}_{1}+\hat{\pi}_{2}+\cdots+\hat{\pi}_{J}=1$, maka diperoleh

$$
\begin{aligned}
& \hat{\pi}_{1}=\frac{1}{1+\sum_{j=2}^{J} \exp \left(x_{j}{ }^{T} b_{j}\right)} \\
& \hat{\pi}_{j}=\frac{\exp \left(x_{j}{ }^{T} b_{j}\right)}{1+\sum_{j=2}^{J} \exp \left(x_{j}{ }^{T} b_{j}\right)}, \text { untuk } j=2,3, \ldots, J
\end{aligned}
$$

Untuk regresi Logistik Nominal, variabel penjelas dapat berupa kategorik atau kontinu. Pemilihan kategori acuan untuk variabel respon dapat mempengaruhi pendugaan parameter $b$ tetapi tidak pada pendugaan peluang $\hat{\pi}$.

\section{Data dan Metode}

Data yang digunakan dalam penelitian ini adalah data sekunder berdasarkan data rekam medik pasien rawat inap yang diambil secara acak di RS. Dr. Wahidin Sudirohusodo Makassar. Pengambilan data dibatasi pada data rekam medik pasien penderita penyakit Diabetes Mellitus jenis tipe II dan pasien yang berumur 25 tahun ke atas yang pernah atau sedang menjalani rawat inap di RS. Dr. Wahidin Sudirohusodo Makassar. Data dimulai dari Januari 2005 s/d Mei 2006, dengan jumlah sampel sebanyak 102 kasus. Indikator variabel yang diamati diberikan pada Tabel 1 di bawah.

Variabel yang digunakan sebagai respon adalah status kelangsungan hidup pasien yang dibagi dalam 4 kategori yaitu sembuh, belum sembuh atau pulang paksa, membaik atau berobat jalan, dan kategori terakhir meninggal. Sedangkan variabel yang digunakan sebagai variabel penjelas sebanyak 13 variabel, dimana 6 diantaranya merupakan variabel yang berskala numerik yaitu umur, berat badan, tinggi badan, lama menderita penyakit DM, lama dirawat di rumah sakit, dan kadar gula darah pasien. Sedangkan 7 variabel penjelas berskala kategorik yaitu jenis kelamin, jenis pekerjaan, tingkat pendidikan, jenis penyakit, komplikasi, diet DM, dan kategori NIDD. Variabel-varibel kategorik ini masing-masing diuraikan lagi ke dalam kategorinya masing-masing.

Proses pengolahan data dengan model regresi Logistik Nominal dilakukan dengan menggunakan bantuan paket program Minitab versi 13. Dan sebagai kategori acuan pada variabel respon atau variabel status kelangsungan hidup pasien penderita penyakit ini digunakan kategori meninggal. 
Anisa

Tabel 1. Jenis Data /Variabel yang Diamati

\begin{tabular}{|c|l|c|}
\hline No & Jenis Variabel/Data yang Diamati & \multicolumn{1}{|c|}{ Keterangan } \\
\hline 1 & Status Kelangsungan Hidup & Sebagai Variabel Respon \\
\hline 2 & Kadar Gula Darah (mg/dl) & \\
3 & Jenis Kelamin & \\
4 & Umur (tahun) & \\
5 & Jenis Pekerjaan & Sebagai Variabel Penjelas \\
6 & Tingkat Pendidikan & \\
7 & Berat Badan (kg) & \\
8 & Tinggi Badan (cm) & \\
9 & Lama Menderita Penyakit DM & \\
10 & Lama Dirawat di Rumah Sakit & \\
11 & Jenis Penyakit & \\
12 & Komplikasi & \\
13 & Diet Diabetes Mellitus (DDM) & \\
14 & Kategori NIDDM & \\
\hline
\end{tabular}

\section{Hasil dan Pembahasan}

\subsection{Deskripsi Variabel yang Digunakan}

Dalam analisis status kelangsungan hidup pasien penderita penyakit DM ini, variabel penjelas yang digunakan berupa variabel kategorik dan numerik.

Distribusi variabel penjelas untuk variabel kategorik diberikan pada Tabel 2 berikut.

Tabel 2. Distribusi Variabel Penjelas Kategorik Penderita Penyakit Diabetes Mellitus di

RS. Dr. Wahidin Sudirohusodo Makassar periode Januari 2005 s/d Mei 2006

\begin{tabular}{|c|c|c|c|}
\hline No & $\begin{array}{c}\text { Nama Variabel Kategorik dan } \\
\text { Kodenya Masing-Masing }\end{array}$ & Frekuensi & Persentase $(\%)$ \\
\hline 1 & $\begin{array}{l}\text { Jenis Kelamin } \\
-\quad 1=\text { Perempuan } \\
-\quad 2=\text { Laki-laki }\end{array}$ & $\begin{array}{l}53 \\
49\end{array}$ & $\begin{array}{l}51.96 \\
48.04\end{array}$ \\
\hline 2 & $\begin{array}{ll}\text { Jenis Pekerjaan } \\
-\quad 1=\text { PNS } \\
-\quad 2=\text { Pengusaha/Wiraswasta } \\
-\quad 3=\text { Guru/Dosen } \\
-\quad 4=\text { Pensiunan PNS/ABRI } \\
-\quad 5=\text { Ibu Rumah Tangga } \\
-\quad 6=\text { Tidak Bekerja }\end{array}$ & $\begin{array}{c}36 \\
12 \\
2 \\
13 \\
30 \\
9 \\
\end{array}$ & $\begin{array}{c}35.29 \\
11.76 \\
1.96 \\
12.75 \\
29.41 \\
8.82\end{array}$ \\
\hline 3 & $\begin{array}{ll}\text { Tingkat Pendidikan } \\
-\quad 1=\text { SD Sederajat } \\
-\quad 2=\text { SMP Sederajat } \\
-\quad 3=\text { SMA Sederajat } \\
-\quad 4=\text { DIPLOMA } \\
-\quad 5=\text { S1 ke atas }\end{array}$ & $\begin{array}{c}18 \\
24 \\
21 \\
8 \\
31\end{array}$ & $\begin{array}{c}17.65 \\
23.53 \\
20.59 \\
7.84 \\
30.39\end{array}$ \\
\hline
\end{tabular}


Anisa

Tabel 2. lanjutan

\begin{tabular}{|c|c|c|c|}
\hline No & $\begin{array}{c}\text { Nama Variabel Kategorik dan } \\
\text { Kodenya Masing-Masing }\end{array}$ & Frekuensi & Persentase $(\%)$ \\
\hline 4 & $\begin{array}{l}\text { Jenis Penyakit DM } \\
-\quad 1=\text { DM Tipe II Non Obese } \\
-\quad 2=\text { DM Tipe II Obese } \\
-\quad 3=\text { Lain-lain }\end{array}$ & $\begin{array}{c}29 \\
6 \\
67\end{array}$ & $\begin{array}{c}28.43 \\
5.88 \\
65.69\end{array}$ \\
\hline 5 & $\begin{array}{ll}\text { Komplikasi } \\
-\quad 1=\text { Disfungsi Ereksi } \\
-\quad 2=\text { Kegagalan Ginjal } \\
-\quad 3=\text { Gangguan Mata dan Kebutaan } \\
-\quad 4=\text { Nyeri Seluruh Tubuh } \\
-\quad 5=\text { Stroke/Lumpuh (Hipertensi) } \\
-\quad 6=\text { Gangguan Jantung dan Saluran Cerna } \\
-\quad 7=\text { Kaki Diabet dan Amputasi Diabetes } \\
-\quad 8=\text { Tanpa Komplikasi } \\
-\quad 9=\text { Lain-lain }\end{array}$ & $\begin{array}{c}0 \\
0 \\
0 \\
0 \\
40 \\
18 \\
13 \\
5 \\
26\end{array}$ & $\begin{array}{c}0.00 \\
0.00 \\
0.00 \\
0.00 \\
39.22 \\
17.65 \\
12.75 \\
4.90 \\
25.49\end{array}$ \\
\hline 6 & $\begin{array}{ll}\text { Diet DM } \\
-\quad 1=\text { Diet DM } 1500 \text { Kalori } \\
-\quad 2=\text { Diet DM } 1700 \text { Kalori } \\
-\quad 3=\text { Diet DM } 1900 \text { Kalori } \\
-\quad 4=\text { Diet DM } 2300 \text { Kalori } \\
-\quad 5=\text { Tidak Diet DM }\end{array}$ & $\begin{array}{c}13 \\
45 \\
16 \\
2 \\
26\end{array}$ & $\begin{array}{c}12.75 \\
44.12 \\
15.69 \\
1.96 \\
25.49\end{array}$ \\
\hline 7 & $\begin{array}{l}\text { Kategori NIDDM } \\
-\quad 1=\text { NIDDM Sudah Dikenal terkontrol } \\
-\quad 2=\text { NIDDM Sudah Dikenal Tidak terkontrol } \\
-\quad 3=\text { NIDDM Belum Dikenal }\end{array}$ & $\begin{array}{l}22 \\
49 \\
31\end{array}$ & $\begin{array}{l}21.57 \\
48.04 \\
30.39\end{array}$ \\
\hline
\end{tabular}

Berdasarkan Tabel 2 menunjukkan bahwa penderita penyakit DM berjenis kelamin perempuan sebesar 53 kasus (51.96\%) lebih banyak dibandingkan dengan penderita yang berjenis kelamin laki-laki sebesar 49 kasus (48.04\%). Kejadian DM tertinggi menurut jenis pekerjaan terdapat pada pasien yang bekerja sebagai PNS sebesar 36 kasus (35.29\%), diikuti penderita yang bekerja sebagai ibu rumah tangga sebesar 30 kasus (29.41\%) sedangkan yang terendah yang bekerja sebagai guru/dosen sebesar 2 kasus (4.76\%). Kejadian penyakit DM tertinggi menurut tingkat pendidikan terdapat pada tingkat pendidikan S1 ke atas sebesar 21 kasus (30.39\%), sedangkan yang terendah pada tingkat pendidikan Diploma sebesar 8 kasus (7.84\%). Kejadian penyakit DM tertinggi menurut jenis penyakit DM terdapat pada jenis penyakit lain-lain sebesar 67 kasus (65.69\%), sedangkan yang terendah pada pasien dengan jenis penyakit DM tipe II obese sebesar 6 kasus (5.88\%). Jenis penyakit DM yang dimaksudkan adalah pasien yang tidak dikenali menderita DM tipe II obese atau non obese tetapi DM yang disebabkan karena hal yang lain seperti pola makan yang salah, proses penuaan, atau karena stress yang mengakibatkan terjadinya resistensi insulin. Kejadian penyakit DM tertinggi menurut komplikasi yang terjadi terdapat pada komplikasi stroke/lumpuh (hipertensi) sebesar 40 kasus (39.22\%), sedangkan yang terendah pada pasien yang tidak memiliki komplikasi sebesar 5 kasus (4.90\%). Kejadian DM tertinggi menurut diet DM yang dilakukan terdapat pada pasien dengan diet DM 1700 sebesar 45 kasus (44.12\%), sedangkan yang terendah pada pasien dengan diet DM 2300 kalori sebesar 2 kasus (1.96\%). Kejadian DM tertinggi menurut kategori NIDDM terdapat pada kategori NIDDM sudah dikenal tetapi tidak terkontrol sebesar 49 kasus (48.04\%), sedangkan yang terendah pada pasien dengan kategori NIDDM sudah dikenali dan terkontrol sebesar 22 kasus (21.57\%). 


\section{Anisa}

Sedangkan variabel numerik yang digunakan deskripsinya diberikan pada Tabel 3 berikut.

Tabel 3. Deskripsi Variabel Penjelas Numerik Penderita Penyakit Diabetes Mellitus di

RS. Dr. Wahidin Sudirohusodo Makassar periode Januari 2005 s/d Mei 2006

\begin{tabular}{|c|l|c|c|c|}
\hline No & Nama Variabel Numerik & Rata-Rata & Nilai Minimum & Nilai Maksimum \\
\hline 1 & Umur (tahun) & 59 & 30 & 87 \\
2 & Berat Badan (kg) & 58.67 & 37 & 85 \\
3 & Tinggi Badan (cm) & 156 & 149 & 175 \\
4 & Lama Menderita (tahun) & 3.4 & 0 & 28 \\
5 & Lama Dirawat (hari) & 11 & 1 & 86 \\
6 & Kadar Gula Darah (mg/dl) & 216.5 & 23 & 479 \\
\hline
\end{tabular}

Dari Tabel 3 terlihat distribusi pasien menurut umur menunjukkan bahwa rata-rata umur penderita penyakit DM adalah 59 tahun, pasien termuda dengan umur 30 tahun dan tertua dengan umur 87 tahun. Distribusi pasien menurut berat badan menunjukkan bahwa rata-rata berat badan penderita penyakit DM adalah $58.67 \mathrm{~kg}$, berat badan pasien terendah adalah $37 \mathrm{~kg}$ dan tertinggi adalah 85 kg. Distribusi pasien menurut lama rawat menunjukkan bahwa rata-rata lama dirawat penderita penyakit DM adalah 11 hari, yang paling lama mendapatkan perawatan di rumah sakit adalah selama 86 hari dan perawatan tercepat adalah 1 hari. Sedangkan distribusi menurut kadar gula darah pasien, menunjukkan rata-rata kadar gula darah penderita penyakit ini adalah $216.5 \mathrm{mg} / \mathrm{dl}$, dengan kadar gula darah tertinggi $479 \mathrm{mg} / \mathrm{dl}$ dan yang terendah $23 \mathrm{mg} / \mathrm{dl}$.

\subsection{Model Regresi Logistik Nominal}

Model regresi Logistik Nominal untuk masing-masing kategori status kelangsungan hidup terhadap kategori acuan meninggal yang diperoleh diuraikan berikut ini. Sedangkan hasil pengujian model secara keseluruhan, diperoleh nilai Chi-kuadrat model baik melalui metode Pearson maupun Deviance memberikan hasil yang signifikan (semua nilai $p$-value $<\alpha=0.05$ ), sehingga dapat dikatakan model yang dihasilkan layak relatif terhadap data yang digunakan.

- $\quad$ Untuk status kelangsungan hidup pasien kategori sembuh terhadap yang meninggal, model regresi Logistik Nominal yang diperoleh adalah :

$$
\begin{aligned}
\log \left(\frac{\pi_{1}}{\pi_{4}}\right) & =-149+0.13 x_{1}+15.0 x_{2}-0.42 x_{3}-7.20 x_{4}-6.00 x_{5}-0.10 x_{6} \\
& +1.00 x_{7}-3.50 x_{8}+0.87 x_{9}+5.00 x_{10}+1.00 x_{11}-6.00 x_{12}-19.00 x_{13}
\end{aligned}
$$

dimana variabel $x_{1}-x_{13}$ berturut-turut adalah kadar gula darah pasien, jenis kelamin, umur, pekerjaan, tingkat pendidikan, berat badan, tinggi badan, lama pasien menderita penyakit ini, lamanya pasien dalam perawatan di rumah sakit, jenis penyakit, komplikasi, diet DM yang dilakukan dan kategori penyakit.

- Untuk status kelangsungan hidup pasien kategori belum sembuh atau pulang paksa terhadap yang meninggal, model regresi Logistik Nominal yang diperoleh adalah :

$$
\begin{aligned}
& \log \left(\frac{\pi_{2}}{\pi_{4}}\right)=14.640-0.00 x_{1}-2.45 x_{2}-0.04 x_{3}-0.07 x_{4}-0.00 x_{5}+0.12 x_{6} \\
& -0.09 x_{7}-0.01 x_{8}-0.01 x_{9}+0.12 x_{10}+0.09 x_{11}-1.68 x_{12}+0.75 x_{13} \text { Untuk status }
\end{aligned}
$$




\section{Anisa}

kelangsungan hidup pasien kategori membaik atau berobat jalan jika dibandingkan terhadap yang meninggal, model regresi Logistik Nominal yang diperoleh adalah:

$$
\begin{gathered}
\log \left(\frac{\pi_{3}}{\pi_{4}}\right)=13,956-0.00 x_{1}-0.83 x_{2}-0.07 x_{3}+0.39 x_{4}+0.50 x_{5}+0.06 x_{6} \\
-0.06 x_{7}-0.04 x_{8}+0.04 x_{9}+0.58 x_{10}-0.24 x_{11}-1.38 x_{12}+0.71 x_{13}
\end{gathered}
$$

Untuk menentukan nilai peluang seorang pasien akan sembuh, membaik atau berobat jalan, belum sembuh atau pulang paksa, dan peluang seorang pasien akan meninggal, maka pada tabel berikut diberikan nilai logit pada beberapa kombinasi nilai prediktor yang diperoleh berdasarkan nilai regresi Logistik Nominal di atas.

Tabel 4. Nilai Regresi Logistik Nominal pada Berbagai Kondisi Nilai Prediktor yang Digunakan

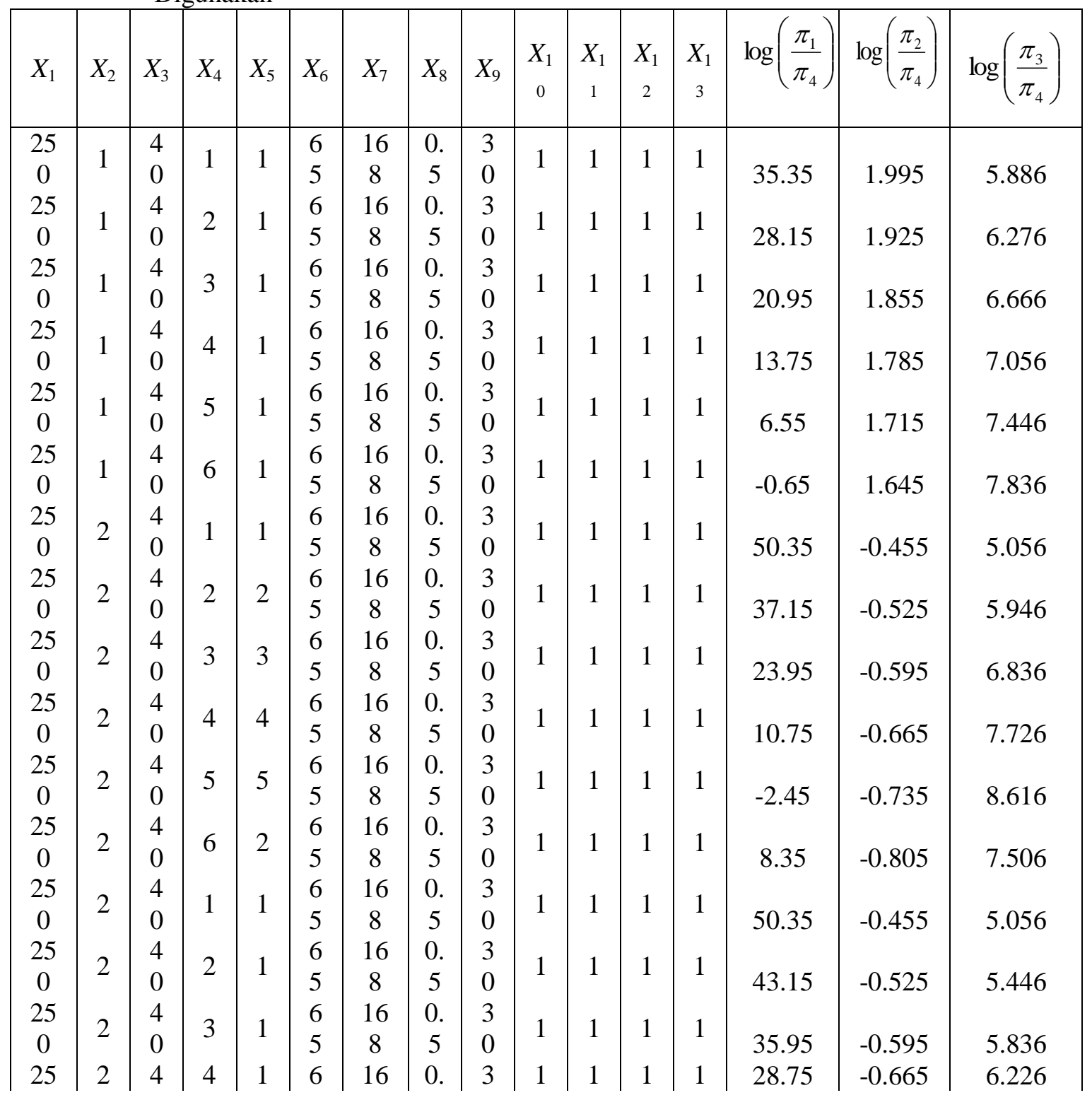




\section{Anisa}

\begin{tabular}{|c|l|l|l|l|l|l|l|l|l|l|l|l|l|l|l|}
0 & 0 & & & 5 & 8 & 5 & 0 & & & & & & & \\
25 & 2 & 4 & 5 & & 6 & 16 & 0. & 3 & 1 & 1 & 1 & 1 & & & \\
0 & 2 & 0 & & 1 & 5 & 8 & 5 & 0 & 1 & & & & 21.55 & -0.735 & 6.616 \\
25 & 2 & 4 & 6 & & 6 & 16 & 0. & 3 & & & & & & & \\
0 & 2 & 0 & & 1 & 5 & 8 & 5 & 0 & 1 & 1 & 1 & 1 & 14.35 & -0.805 & 7.006 \\
$\mathrm{dst}$ & & & & & & & & & & & & & & & \\
\hline
\end{tabular}

Berdasarkan tabel di atas, maka peluang seorang pasien untuk sembuh jika pasien tersebut mempunyai kadar gula darah $250 \mathrm{mg} / \mathrm{dl}\left(x_{1}=250\right)$, jenis kelamin perempuan $\left(x_{2}=1\right)$ yang berumur 40 tahun $\left(x_{3}=40\right)$, seorang PNS $\left(x_{4}=1\right)$ dengan tingkat pendidikan hanya tamatan SD $\left(x_{5}=1\right)$, dengan berat badan $65 \mathrm{~kg}\left(x_{6}=65\right)$ dan tinggi $168 \mathrm{~cm}\left(x_{7}=168\right)$, yang sudah mengidap penyakit ini selama 6 bulan $\left(x_{8}=0.5\right)$, sudah dirawat selama sebulan di rumah sakit ini $\left(x_{9}=30\right)$ dengan diagnosis bahwa jenis penyakitnya termasuk DM tipe II Non Obese $\left(x_{10}=1\right)$ dan komplikasi pada disfungsi ereksi $\left(x_{11}=1\right)$, sehingga diberikan diet DM 1500 kalori $\left(x_{12}=1\right)$ dan NIDDMnya diketahui termasuk dalam kategori sudah dikenal terkontrol $\left(x_{13}=1\right)$, maka peluang untuk sembuh pasien tersebut adalah

$$
\hat{\pi}_{1}=\frac{\exp \left(x_{j}{ }^{T} b_{j}\right)}{1+\sum_{j=2}^{J} \exp \left(x_{j}{ }^{T} b_{j}\right)}=\frac{\exp (35.35)}{1+\exp (35.35)+\exp (1.995)+\exp (5.886)} \approx 1.0000
$$

Sedangkan peluang pasien tersebut untuk belum sembuh/pulang paksa, dan membaik/berobat jalan adalah

$$
\begin{gathered}
\hat{\pi}_{2}=\frac{\exp \left(x_{j}{ }^{T} b_{j}\right)}{1+\sum_{j=2}^{J} \exp \left(x_{j}{ }^{T} b_{j}\right)}=\frac{\exp (1.995)}{1+\exp (35.35)+\exp (1.995)+\exp (5.886)} \approx 0.0000 \\
\hat{\pi}_{3}=\frac{\exp \left(x_{j}{ }^{T} b_{j}\right)}{1+\sum_{j=2}^{J} \exp \left(x_{j}{ }^{T} b_{j}\right)}=\frac{\exp (5.886)}{1+\exp (35.35)+\exp (1.995)+\exp (5.886)} \approx 0.0000
\end{gathered}
$$

Sehingga peluang pasien penderita DM tersebut untuk meninggal adalah :

$$
\hat{\pi}_{4}=1-\hat{\pi}_{3}-\hat{\pi}_{2}-\hat{\pi}_{1}=1-0.0000-0.0000-1.0000=0.0000
$$

Dengan cara yang sama, nilai peluang seorang penderita DM untuk sembuh, membaik/berobat jalan, belum sembuh/pulang paksa dan meninggal untuk berbagai kombinasi peubah prediktor yang digunakan, dimana beberapa di antaranya diberikan pada Tabel 4, dapat ditentukan.

\section{Kesimpulan dan Saran}

Berdasarkan analisis yang telah dilakukan maka disimpulkan bahwa analisis regresi Logistik Nominal layak digunakan untuk memodelkan status kelangsungan hidup penderita penyakit Diabetes Mellitus (DM) di RS. Wahidin Sudirohusodo Makassar. Peluang seorang pasien akan sembuh, membaik atau berobat jalan, belum sembuh atau pulang paksa, bahkan meninggal untuk berbagai kombinasi peubah prediktor yang digunakan dalam model dapat ditentukan. Model ini bisa dijadikan sebagai acuan kepada pihak rumah sakit untuk meningkatkan 


\section{Anisa}

pelayanan dan pengambilan tindakan yang diperlukan untuk semakin meningkatkan pelayanannya.

Kajian lanjut dapat dilakukan pada status kelangsungan hidup pasien kategori sembuh. Dapat dilakukan analisis lebih mendalam untuk mengetahui penyebab pengujian parameter model tidak signifikan.

\section{Ucapan Terima Kasih}

Ucapan terima kasih penulis sampaikan kepada Program Hibah Kompetisi (PHK) A2 Jurusan Matematika FMIPA UNHAS yang telah mendukung penelitian ini melalui kegiatan Hibah Penelitian tahun 2006. Ucapan terima kasih juga disampaikan kepada pihak manajemen RS. Wahidin Sudirohusodo yang telah bersedia untuk memberikan akses ke bagian Data Rekam Medik rumah sakit tersebut.

\section{Daftar Pustaka}

[1] Agresti A, 1990, "Categorical Data Analysis", John Wiley \& Sons, Canada.

[2] Hosmer DW, Lemeshow S, 1989, "Applied Logistic Regression", John Wiley \& Sons, Canada.

[3] Johnson M, 1998, "Diabetes, Terapi dan Pencegahannya", Indonesia Publishing House, Bandung.

[4] Lee ET, 1992, "Statistical Methods for Survival Data Analysis, Second Edition", John Wiley \& Sons, Canada.

[5] Tim Redaksi Vitahealth, 2004, "Diabetes", PT. Gramedia Pustaka Utama, Jakarta.

[6] Tiro MA, 2004, "Analisis Regresi dengan Data Kategorik, Edisi Kedua", Badan Penerbit UNM, Makassar.

[7] Yong MYM, Penyakit kencing manis, http://us.geocities.com/maizurahm [1 Agustus 2006]. 